\title{
Biochar on Soil Chemical Properties and Beak Pepper (Capsicun chinense) Production
}

\author{
Gilvanise Alves Tito $\mathbb{(}^{\circ}$, Lúcia Helena Garófalo Chaves* ${ }^{\circledR}$, Edilma Rodrigues Bento Dantas $(\mathbb{D}$,

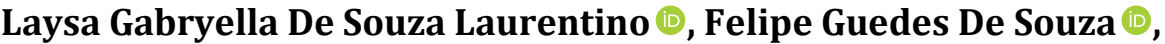 \\ Hugo Orlando Carvallo Guerra
}

Department of Agricultural Engineering, Federal University of Campina Grande (DEAG/UFCG), Campina Grande, Brazil Email: gilvanisetito@yahoo.com.br, *lhgarofalo@hotmail.com, edilma.dantas@hotmail.com, laysaagabryella@live.com, felipeguedes.eng@gmail.com, hugo_carvallo@hotmail.com

How to cite this paper: Tito, G.A., Garófalo Chaves, L.H., Danta, E.R.B., De Souza Laurentino, L.G., De Souza, F.G. and Guerra, H.O.C. (2020) Biochar on Soil Chemical Properties and Beak Pepper (Capsicun chinense) Production. Agricultural Sciences, 11, 1133-1142.

https://doi.org/10.4236/as.2020.1112074

Received: November 11, 2020

Accepted: December 13, 2020

Published: December 16, 2020

Copyright $\odot 2020$ by author(s) and Scientific Research Publishing Inc. This work is licensed under the Creative Commons Attribution International License (CC BY 4.0).

http://creativecommons.org/licenses/by/4.0/

\begin{abstract}
The transformation and recycling of poultry litter through the pyrolysis process produces a co-product called biochar which, applied to the soil, improves the chemical characteristics of the soil and is used as a soil fertilizer due to its high content of nutrients to plants. The objective of this study was to assess the effect of biochar, produced from poultry litter wastes on soil chemical properties and the culture of the beak pepper (Capsicun chinense). For this, the experimental units, corresponding to plastic vessels, were prepared with $5 \mathrm{~kg}$ of soil mixed with increasing doses of biochar: $0 ; 2.5 ; 5.0 ; 7.5$ and $10 \mathrm{t} \cdot \mathrm{ha}^{-1}$, with three replications. This material (soil + biochar) was incubated for 20 days keeping the humidity close to the field capacity. After this period, soil samples from the experimental units were collected and then chemically analyzed. The seedlings of pepper were produced in a greenhouse and transplanted to the experimental units when the seedlings were $15 \mathrm{~cm}$ tall. After 10 days of transplanting, thinning was done, leaving a plant/vessel. Biometric variables were analyzed at 120 DAS, after fruit harvesting: plant height $(\mathrm{PH})$, stem diameter (SD), fresh shoot biomass (FSB), fresh fruit biomass (FFB), dry biomass of the aerial part (DSB) and the fruits (DFB). The results were submitted to analysis of variance and regression by orthogonal polynomials using the statistical program SISVAR. Biochar improved the soil chemical properties using as an acidity corrective and source of nutrients, mainly phosphorus and potassium. The doses used, in general, favored the development and production of the beak pepper, increasing the fresh shoot biomass, the fresh and dry fruit biomass. To improve the soil chemical properties, the highest biochar dose is recommended, that is, 10 ton $\cdot \mathrm{ha}^{-1}$, however, this dose can harm the production of pepper fruits, so for this crop 5 ton $\cdot \mathrm{ha}^{-1}$ should be recommended.
\end{abstract}




\section{Keywords}

Poultry Litter, Pyrolysis, Vegetable, Capsicun chinense

\section{Introduction}

The intensive use of highly soluble chemical fertilizers corresponds to a large part of the production costs in agricultural systems and can cause impacts on the environment [1]. On the other hand, the growth, in Brazil, of the demand for the production of healthier and more sustainable food, has been seeking alternative fertilization that can contribute in a beneficial way to sustainable development. The use of waste as a source of nutrients for plants and improving soil quality is a form of safe disposal in the environment.

One way of using these organic residues is through the pyrolysis of this material, thereby making $\mathrm{C}$ more stable in the produced biochar compared to the original biomass [2]. Biochar is the term given to the material resulting from the thermal degradation (pyrolysis) of organic matter with little or no oxygen present [3], quickly or slowly. Its nutritional characteristics vary depending on the material used in pyrolysis, but there is usually an increase in the capacity for cation exchange, macronutrients, micronutrients and $\mathrm{pH}$ [4] [5]. According to some authors Faria et al. [6] and Lima et al. [7], the use of biochar in agriculture promotes an increase in crop productivity due to the greater absorption of nutrients by plants.

In recent years, accompanying the growth of the national the chicken meat production, significant amounts of waste were generated, such as poultry litter. This poultry litter is used as a soil fertilizer due to its high content of nitrogen, phosphorus and calcium. When this material is applied directly to the soil without any previous treatment, it becomes a potential contaminant, capable of polluting agricultural soils with pathogens, antibiotics, pesticides and heavy metals that can accumulate in the superficial layers of the soil and contaminate bodies of water becoming bio unavailable and phytotoxic, compromising crop quality [8] [9]. With the huge amount of chicken wasted biomass, biochar comes as an obvious solution for urgent problems: a fast, inexpensive and opportune way to dispose of poultry litter, stock carbon and improve soil quality.

Although environmental and agricultural benefits are well described in various studies [10] [11] [12] [13], there is not in pepper plant responses to the application of poultry litter biochar to soil.

The beak pepper (Capsicun chinense), belonging to the Solanaceae family and to the genus Capsicum, originates in the Western Hemisphere, having a triangular shape with a very pointed tip, forming a pout, with approximately 2.5 to $2.8 \mathrm{~cm}$ in length and $1.5 \mathrm{~cm}$ wide, due to great diversity, in terms of colors, with a predominance of red coloring [14]. This pepper quickly gained national expression for presenting extremely tasty and aromatic fruits, characterized mainly 
by its sweet and pungent flavor [15]. In addition to being consumed fresh, peppers supply the agribusiness and can be processed in the form of sauces, preserves and jellies, also covering the sale of ornamental plants [16].

The cultivation of peppers, in several Brazilian states, has been expanding in recent years, due to the growing demand from the domestic and foreign markets, and according to [17], adapts to family farming and integration between small farmers and agribusiness.

Mineral nutrition directly influences the growth and production of plants, where it is essential to increase productivity and improve the quality of harvested products. Embrapa Hortaliças [18], reports that limestone is essential in pepper cultivation, since the base saturation must be increased to $80 \%$ and the minimum magnesium content to $8 \mathrm{mmol} \cdot \mathrm{dm}^{-3}$. In addition to the use of nitrogen, phosphorus and potassium and the application of boron and zinc, organic fertilization, approximately $10 \mathrm{t} \cdot \mathrm{ha}^{-1}$, should be used if chicken manure or $30 \mathrm{t} \cdot \mathrm{ha}^{-1}$ of cattle manure.

Considering that pepper plants need adequate nutrients for their development, it is important to apply organic fertilizer when planting them, both for their nutritional form and to reduce production costs in family farming and that biochar is a promising product as use of fertilizer, the present study was to assess the effect of poultry litter biochar on soil chemical properties and the culture of the beak pepper (Capsicun chinense). Since it is expected that the incubation of biochar to the soil, increase soil fertility by nutritional enrichment of the soil and consequently improve the production of this culture.

\section{Materials and Methods}

The trial was carried out in a greenhouse using Dystrophic Gray Argisol samples collected in the superficial layer $(0-20 \mathrm{~cm})$ from the Agreste Region of Paraíba. These samples were air-dried, crushed, sieved through a $2 \mathrm{~mm}$ sieve and its physical and chemical characteristics were obtained according to the methodologies described by [19] with the following results: clay $=40.0 \mathrm{~g} \cdot \mathrm{kg}^{-1}$, silt $=90.4$ $\mathrm{g} \cdot \mathrm{kg}^{-1}$ and sand $=869.6 \mathrm{~g} \mathrm{~kg}^{-1} ; \mathrm{pH}_{\text {(H2O) }}=5.42 ; \mathrm{Ca}=2.2 \mathrm{cmol}_{\mathrm{c}} \cdot \mathrm{kg}^{-1} ; \mathrm{Mg}=2.4$ $\mathrm{cmol}_{c} \cdot \mathrm{kg}^{-1} ; \mathrm{Na}=0.04 \mathrm{cmol}_{c} \cdot \mathrm{kg}^{-1} ; \mathrm{K}=0.11 \mathrm{cmol}_{c} \cdot \mathrm{kg}^{-1} ; \mathrm{H}+\mathrm{Al}=2.38 \mathrm{cmol}_{c} \cdot \mathrm{kg}^{-1} ; \mathrm{P}$ $=3.8 \mathrm{mg} \cdot \mathrm{kg}^{-1} ; \mathrm{OM}=17.9 \mathrm{~g} \cdot \mathrm{kg}^{-1}, \mathrm{CEC}=7.13 \mathrm{cmol}_{\mathrm{c}} \cdot \mathrm{kg}^{-1}$.

This biochar was produced in the Irrigation and Salinity Laboratory submitting the poultry litter wastes to a slow pyrolysis at $350^{\circ} \mathrm{C}$ for 3 hours at a heating rate of $10^{\circ} \mathrm{C} \cdot \mathrm{min}^{-1}$ in a muffle furnace. It was removed from the muffle only after it had completely cooled down, around 24 hours. After pyrolysis, the biochar was grounded and passed through a $2 \mathrm{~mm}$ sieve to be used in the experiments.

The poultry litter biochar was chemically characterized, according to the manual of official analytical methods for fertilizers and correctives [20], presenting the following attributes: Total Nitrogen $\left(\mathrm{g} \cdot \mathrm{kg}^{-1}\right)=30.6$; Phosphorus $\left(\mathrm{P}_{2} \mathrm{O}_{5}\right)$ Total $(\%)=5.76 ;$ Potassium $\left(\mathrm{K}_{2} \mathrm{O}\right)(\%)=6.61 ; \mathrm{Ca}(\%)=5.27 ; \mathrm{Mg}(\%)=1.08 ; \mathrm{pH}=$ 8.97; Organic carbon $\left(\mathrm{g} \cdot \mathrm{kg}^{-1}\right)=400.2$; Carbon/Nitrogen ratio $=13.08$ and CEC $\left(\mathrm{cmol}_{\mathrm{c}} \cdot \mathrm{kg}^{-1}\right)=58.61$. 
The experimental units, corresponding to plastic vessels, were prepared with 5 $\mathrm{kg}$ of soil, previously dried, sieved and mixed with increasing doses of biochar. After the preparation of the experimental units, the material (soil + biochar) was incubated for 20 days keeping the humidity close to the field capacity. After this period, soil samples from the experimental units were collected and then chemically analyzed.

The seedlings of pepper (Capsicun chinense) were produced in a greenhouse, using coconut fiber substrate in trays suitable for sowing. After sowing, transplantation to the experimental units was carried out when the seedlings were, on average, $15 \mathrm{~cm}$ tall. After 10 days of transplanting, thinning was done, leaving a plant/vessel.

The experimental design used was entirely randomized, comprising the following increasing doses of biochar: $0 ; 2.5 ; 5.0 ; 7.5$ and $10 \mathrm{t} \cdot \mathrm{ha}^{-1}$, with three replications, totaling 15 experimental units.

The irrigation of the plants was done with water supply, keeping the soil moisture close to the field capacity. Mineral fertilization was not done to not mask the effects of the treatments.

Biometric variables were analyzed at 120 DAS, after fruit harvesting: plant height (PH), stem diameter (SD), fresh shoot biomass (FSB) and fresh fruit biomass (FFB) and then all the material was placed in an oven at $65^{\circ} \mathrm{C}$ to determine the dry biomass of the aerial part (DSB) and the fruits (DFB).

The results were submitted to analysis of variance and regression by orthogonal polynomials using the statistical program SISVAR [21]. The program's name SISVAR, came from, in that "Sis" refers to the abbreviation of system in Portuguese and "var", the abbreviation of variance. Thus the SISVAR system consists of an analysis of variance statistical program.

\section{Results and Discussion}

After applying biochar to the soils and incubating for 20 days, with the exception of electrical conductivity (EC), the biochar doses affected significantly influenced the chemical properties of the soil (Table 1).

Table 1. Analysis of variance for the $\mathrm{pH}$, electrical conductivity (EC), calcium (Ca), magnesium $(\mathrm{Mg})$, sodium $(\mathrm{Na})$, potassium $(\mathrm{K})$, organic matter $(\mathrm{OM})$, phosphorus $(\mathrm{P})$, base sum (BS) in soil after incubation period with biochar.

\begin{tabular}{|c|c|c|c|c|c|c|c|c|c|c|}
\hline \multirow{2}{*}{$\begin{array}{l}\text { Source of } \\
\text { Variation }\end{array}$} & \multirow{2}{*}{$\mathrm{DF}$} & \multicolumn{9}{|c|}{ Mean Square } \\
\hline & & $\mathrm{pH}$ & $\mathrm{EC}$ & $\mathrm{Ca}$ & $\mathrm{Mg}$ & $\mathrm{Na}$ & $\mathrm{K}$ & $\mathrm{OM}$ & $\mathrm{P}$ & BS \\
\hline $\begin{array}{c}\text { Biochar } \\
\text { treatments }\end{array}$ & 4 & $0.91^{* *}$ & $0.58 \mathrm{~ns}$ & $0.22^{*}$ & $0.52^{*}$ & $0.144^{\star *}$ & $2.57^{\star *}$ & $122.57^{\star *}$ & $21,361.22^{\star *}$ & $5.70^{* *}$ \\
\hline Error & 10 & 0.009 & 0.17 & 0.05 & 0.13 & 0.23 & 0.08 & 10.89 & 453.46 & 0.29 \\
\hline CV (\%) & & 1.59 & 27.11 & 8.78 & 12.78 & 25.83 & 21.98 & 15.01 & 16.67 & 7.49 \\
\hline Mean & & 6.07 & 1.52 & 2.56 & 2.81 & 0.59 & 1.28 & 21.98 & 127.75 & 7.23 \\
\hline
\end{tabular}

DF: Degree of Freedom; ${ }^{*}$ and ${ }^{* *}$ : significant $(0.05 \leq \mathrm{p})$ and $(0.01 \leq \mathrm{p})$ probability of error; ns: not significant; CV: Coefficient of Variation. 
With the exception of calcium, exchangeable cation content ( $\mathrm{Na}, \mathrm{Mg}$ and $\mathrm{K}$ ) increased with biochar concentrations (Figure 1), which is in line with previous studies [11] [22] [23]. At the highest dose $\left(10 \mathrm{t} \cdot \mathrm{ha}^{-1}\right)$ poultry litter biochar, increased the soil $\mathrm{Na}, \mathrm{Mg}$ and $\mathrm{K}$ by $0.50,0.93$ and $2.29 \mathrm{cmol}_{\mathrm{c}} \cdot \mathrm{kg}^{-1}$, respectively; i.e., between these values and the control, there were an increased of $151 \%, 39 \%$ and $1754 \%$, respectively.

In addition to the exchangeable cation content $(\mathrm{K}, \mathrm{Ca}$, and $\mathrm{Mg}$ ) increase, $\mathrm{pH}$, available P content, organic matter and sum of bases increased with biochar concentrations (Figure 2).

Soil $\mathrm{pH}$ values increased linearly after the addition of the biochar; at the highest dose of biochar increased the soil $\mathrm{pH}$ by 1.38 units; the available P contente increased $209.99 \mathrm{mg} \cdot \mathrm{kg}^{-1}$; the organic matter increased of $15.29 \mathrm{~g} \cdot \mathrm{kg}^{-1}$ and the
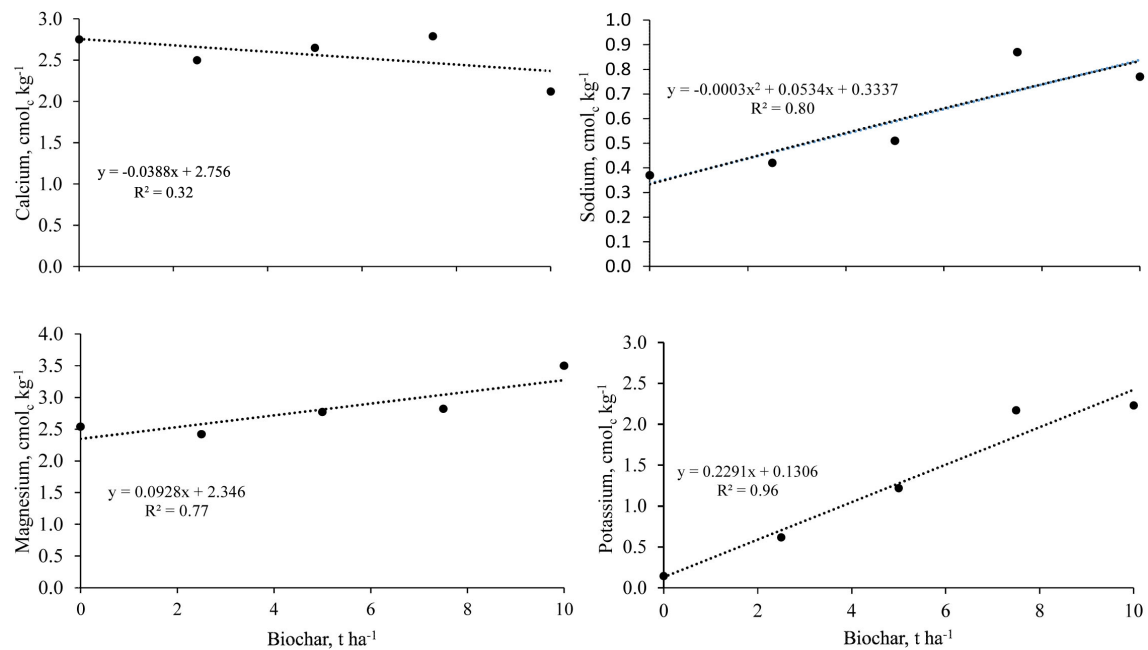

Figure 1. Calcium, sodium, magnesium and potassium after incubation period for the biochar treatments.
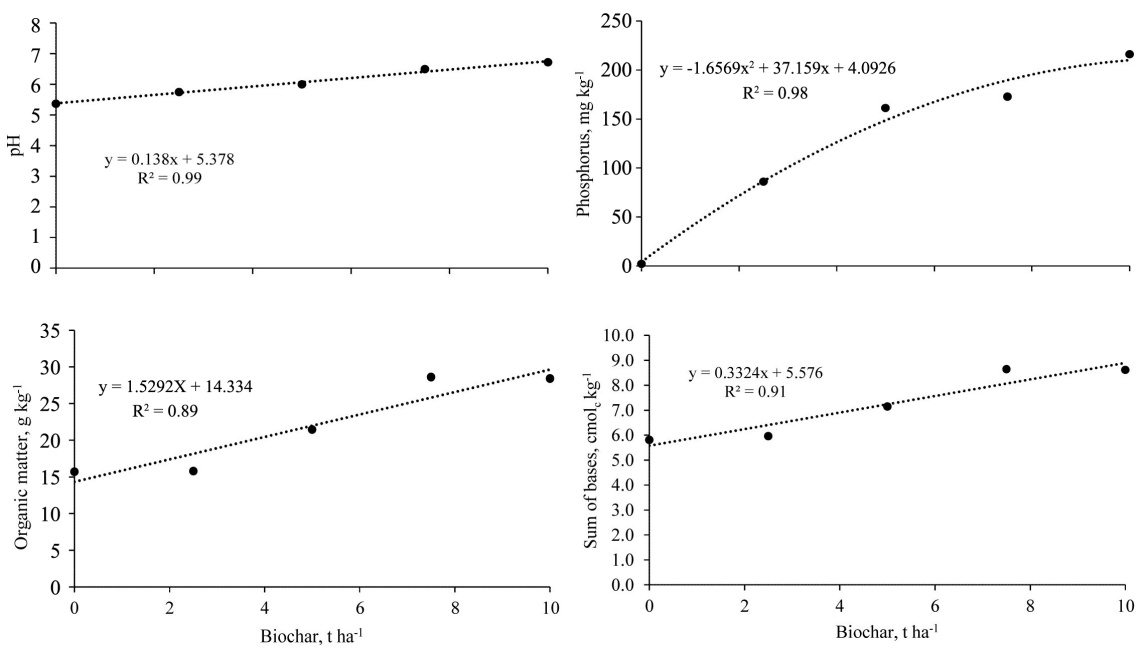

Figure 2. Soil $\mathrm{pH}$ values, phosphorus, organic matter and sum of base after incubation period for the biochar treatments. 
sum of bases increased by $3.324 \mathrm{cmol}_{\mathrm{c}} \cdot \mathrm{kg}^{-1}$, i.e. there were increased of $26 \%$, $5131 \%, 106 \%$ and $60 \%$ in relation to control, respectevely.

According to Sparks [24], changes in soil $\mathrm{pH}$ occur when cations from biochar remove aluminum (Al) from the clay and/or organic matter exchange sites reacting it with soluble monomeric $\mathrm{Al}$ species. Therefore, biochar act on soil as an acidity corrector.

The content of soil organic matter increased linearly with biochar concentrations. This is probably because biochar also undergoes biodegradation, although it is considered stable in the soil system [23].

The significant increase in the phosphorus content of the soil with the biochar application is probably due to the fact that the poultry litter biochar used in this research has in its constitution potassium phosphate $\left(\mathrm{K}_{2} \mathrm{HPO}_{4}\right)$; another possibility could be related to the increase the soil $\mathrm{pH}$ by applying biochar, i.e., when the soil $\mathrm{pH}$ is lower than $5.7, \mathrm{P}$ is predominantly in the form of $\mathrm{H}_{2} \mathrm{PO}_{4}^{-}$ions, which frequently reacts with or is adsorbed by $\mathrm{Fe}$ or $\mathrm{Al}$ compounds to form low-solubility compounds [25].

The increase of the sum of bases with the biochar doses, may be attributed mainly to the potassium content of the biochar, being the sodium and magnesium in second and third place, respectevely. The considerable increase in the potassium content is justified by the presence of compounds such as potassium chloride $(\mathrm{KCl})$, potassium aluminosilicate $\left(\mathrm{KAlSiO}_{4}\right)$ and dibasic potassium phosphate $\left(\mathrm{K}_{2} \mathrm{HPO}_{4}\right)$.

In general, the application of poultry litter biochar in the soil has increased all chemical attributes of the soil, thereby improving the soil fertility level.

Analyzing the summary of the analysis of variance, it appears that the treatments were significant at the level of $p<0.05$ and $p<0.01$ only for the fresh biomass of the aerial part and for the dry biomass of the aerial part, respectively (Table 2).

Table 2. Summary of analysis of variance for fresh shoot biomass (FSB), plant height $(\mathrm{PH})$, stem diameter (SD), dry fruit biomass (DFB) and dry shoot biomass (DSB) of the beak pepper grown with biochar.

\begin{tabular}{ccccccc}
\hline & & \multicolumn{5}{c}{ Mean Square } \\
\cline { 3 - 7 } Source of Variation & $\mathrm{DF}$ & $\mathrm{FSB}^{1}$ & $\mathrm{PH}^{2}$ & $\mathrm{SD}$ & $\mathrm{DFB}^{3}$ & $\mathrm{DSB}$ \\
\cline { 3 - 7 } & & $\mathrm{g}$ & $\mathrm{cm}$ & $\mathrm{mm}$ & $\mathrm{g}$ \\
\hline Biochar treatments & 4 & $6 \mathrm{E}^{-6 *}$ & $4 \mathrm{E}^{-6} \mathrm{~ns}$ & $0.603 \mathrm{~ns}$ & $0.308^{\star *}$ & $20.194 \mathrm{~ns}$ \\
Error & 10 & $1 \mathrm{E}^{-6}$ & $6 \mathrm{E}^{-6}$ & 0.371 & 0.018 & 7.057 \\
CV (\%) & & 0.15 & 9.8 & 6.87 & 10.12 & 28.65 \\
Mean & & 0.71 & 0.02 & 8.87 & 1.33 & 9.27 \\
\hline
\end{tabular}

DF: Degree of Freedom; ${ }^{\star}$ and ${ }^{* *}$ : significant $(0.05 \leq \mathrm{p})$ and $(0.01 \leq \mathrm{p})$ probability of error; ns: not significant; ${ }^{1.2 .3}$ Transformed into $\left(\mathrm{X}^{-1388}-1\right) / 1388 ; 1 / \mathrm{x}$ and $\sqrt{\mathrm{X}}+1$, respectively; CV: Coefficient of Variation. 
According to the treatments, it was verified that thee fresh weight of the aerial part (FSB) increased linearly with increasing concentrations of poultry litter biochar (Figure 3). The addition of $10 \mathrm{t} \cdot \mathrm{ha}^{-1}$ of the biochar led to an increase in FSB from $29.67 \mathrm{~g}$ (control treatment) to $54.57 \mathrm{~g}$ per plant (unprocessed data), promoting an increase of $84.5 \%$ when compared to the control with the highest dose.

The biochar doses significantly influenced the fresh fruit biomass (BFF) in a quadratic way, where the highest BFR value was $1.68 \mathrm{~g} / \mathrm{plant}(1.82 \mathrm{~g} / \mathrm{plant}$, unprocessed data) at the $5.15 \mathrm{t} \cdot \mathrm{ha}^{-1}$ dose (Figure 3), favoring an increase of $75.5 \%$. There was no production of beak pepper in the control (without biochar) and the highest dose of biochar $\left(10 \mathrm{t} \cdot \mathrm{a}^{-1}\right)$, however the data were transformed.

Positive effects on growth of beak pepper plant, after poultry litter biochar application, are associated with the enhancement of soil chemical properties increasing the nutrient availability improving the efficiency of them to plants, especially in sandy soils, as is the case with the present work, where nutrients loss is a major agronomic and environmental problem.

The fresh fruit biomass (FFB) of the piquette pepper did not adjust to the $t$ test, and the Kruskal-Wallis test was applied, where there is a significant difference in doses 2.5; 5.0 and $7.5 \mathrm{t} \cdot \mathrm{ha}^{-1}$ of biochar in relation to the control (Figure 4 ), promoting an increase of $165.7 \% ; 234.3 \%$ and $242.8 \%$, respectively. However, they did not differentiate between themselves. On the other hand, at a dose of 10 $\mathrm{t} \cdot \mathrm{ha}^{-1}$, a significant reduction was observed, which did not differ statistically from the control.

In general, macronutrients in the soil, mainly the levels of potassium and phosphorus, increased due to the increasing doses of biochar; likewise, base saturation reached $90 \%$ (necessary for pepper planting), which indicates that biochar positively affected plant development. However, fruit production was affected by doses 0 and $10 \mathrm{t} \cdot \mathrm{ha}^{-1}$. With the lowest dose, absence of biochar, the nutrients present in the soil were not sufficient for the plants to produce fruit; with the highest dose of biochar, due to the increase in the sodium content in the soil and the electrical conductivity $\left(2.0 \mathrm{dS} \cdot \mathrm{m}^{-1}\right)$ impaired flowering and fruit production. In several experimental units, the plants bloomed, but, quickly, the flowers fell, the plants did not support these flowers until the formation of the fruits. Perhaps other problems may have interfered, such as the lack of micronutrients and/or the deficiency of calcium for the plants.
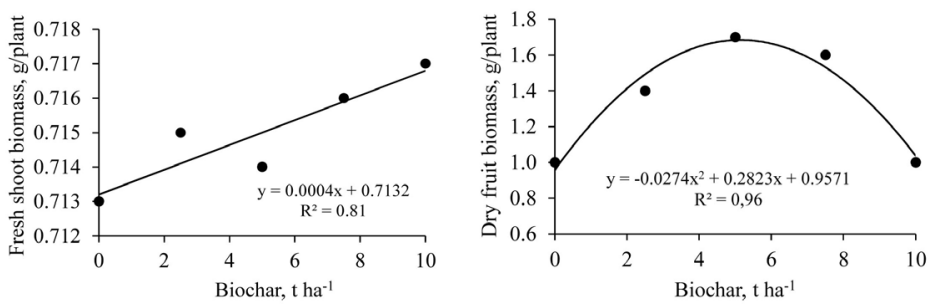

Figure 3. Fresh shoot biomass (FSB) and dry fruit biomass (DFB) of the beak pepper as a function of increasing doses of poultry litter biochar. 


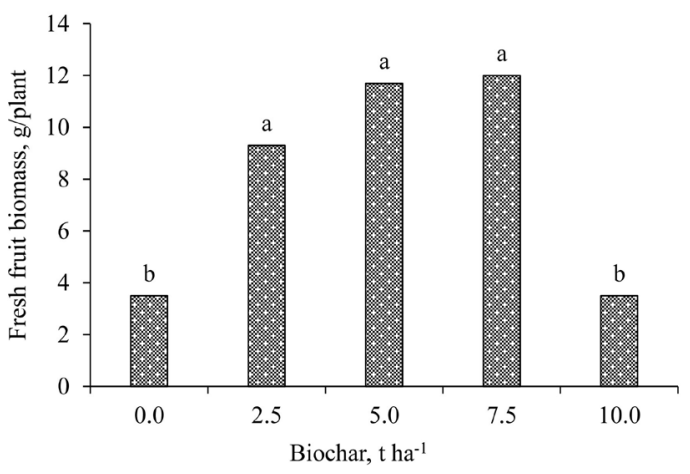

Figure 4. Fresh biomass of the beak pepper fruits as a function of increasing doses of poultry litter biochar. The biomass values followed by the same letter ("a" or "b") do not differ by the Kruskal-Wallis non-parametric test, level of significance $(\alpha=0.05)$, as a function of biochar doses.

\section{Conclusions}

Biochar prepared from the poultry litter improved the soil chemical properties using as an acidity corrective and source of nutrients, mainly phosphorus and potassium.

The doses of biochar used in this research, in general, favored the development and production of the beak pepper, increasing the fresh shoot biomass, the fresh and dry fruit biomass.

To improve the soil chemical properties, the highest biochar dose is recommended, that is, 10 ton $\cdot \mathrm{ha}^{-1}$, however, this dose can harm the production of pepper fruits, so for this crop 5 ton $\cdot \mathrm{ha}^{-1}$ should be recommended.

\section{Acknowledgements}

To the Brazilian National Council for Scientific and Technological Development- $\mathrm{CNPq}$, for granting scholarships to the first author.

\section{Conflicts of Interest}

The authors declare no conflicts of interest regarding the publication of this paper.

\section{References}

[1] Gliessman, S.R. (2005) Agroecologia: Processos Ecológicos em Agricultura Sustentável. 3rd Edition, Editora da UFRGS, Porto Alegre.

[2] Lehmann, J., Gaunt, J. and Rondon, M. (2006) Bio-Char Sequestration in Terrestrial Ecosystems-A Review. Mitigation and Adaptation Strategies for Global Change, 11, 403-427. https://doi.org/10.1007/s11027-005-9006-5

[3] Lehmann, J., Rillig, M., Thies, J., Masiello, C., Hockaday, W.C. and Crowley, D. (2011) Biochar Effects on Soil Biota: A Review. Soil Biology \& Biochemistry, 43, 1812-1836. https://doi.org/10.1016/j.soilbio.2011.04.022

[4] Jeffery, L.S., Verheijen, F.G.A., Van Der Velde, M. and Bastos, A.C. (2011) A Quantitative Review of the Effects of Biochar Application to Soils on Crop Productivity 
Using Meta-Analysis. Agriculture, Ecosystems and Environment, 144, 175-187. https://doi.org/10.1016/j.agee.2011.08.015

[5] Agrafioti, E., Bouras, G., Kalderis, D. and Diamadopoulos, E. (2013) Biochar Production by Sewage Sludge Pyrolysis. Journal of Analytical and Applied Pyrolysis, 101, 72-78. https://doi.org/10.1016/j.jaap.2013.02.010

[6] Faria, W.M., De Figueiredo, C.C., Coser, T.R., Vale, A.T. and Schneider, B.G. (2018) Is Sewage Biochar Capable of Replacing Inorganic Fertilizers for Corn Production? Evidence from a Two-Year Field Experiment. Archives of Agronomy and Soil Science, 64, 505-519. https://doi.org/10.1080/03650340.2017.1360488

[7] De Lima, W.B., Cavalcante, A.R., Bonifácio, B.F., Da Silva, A.A.R., De Oliveira, L.D., Souza, R.F.A. and Chaves, L.H.G. (2019) Growth and Development of Bell Peppers Submitted to Fertilization with Biochar and Nitrogen. Agricultural Sciences, 10, 753-762. https://doi.org/10.4236/as.2019.106058

[8] Masuda, M.M., Abdulaha-Al Baquyb, M., Akhtera, S.R., Sen, A., Barmana, A. and Khatuna, M.R. (2020) Liming Effects of Poultry Litter Derived Biochar on Soil Acidity Amelioration and Maize Growth. Ecotoxicology and Environmental Safety, 202, Article ID: 110865. https://doi.org/10.1016/j.ecoenv.2020.110865

[9] Souza, C.C.B., Sobrinho, N.M.B.A., Lima, E.S.A., Lima, J.O., Carmo, M.G.F. and García, A.C. (2019) Relation between Changes in Organic Matter Structure of Poultry Litter and Heavy Metals Solubility during Composting. Journal of Environmental Management, 247, 291-298. https://doi.org/10.1016/j.jenvman.2019.06.072

[10] Alburquerque, J.A., Calero, J.M., Barrón, V., Torrent, J., Campillo, M.C., Gallardo, A. and Villar, R. (2014) Effects of Biochars Produced from Different Feedstocks on Soil Properties and Sunflower Growth. Journal of Plant Nutrition and Soil Science, 177, 16-25. https://doi.org/10.1002/jpln.201200652

[11] Chan, K.Y., Van Zwieten, L., Meszaros, I., Downie, A. and Joseph, S. (2007) Agronomic Values of Greenwaste Biochar as a Soil Amendment. Australian Journal of Soil Research, 45, 629-634. https://doi.org/10.1071/SR07109

[12] Mukherjee, A. and Lal, R. (2016) Biochar and Soil Quality. CRC Press, Boca Raton.

[13] Uzoma, K.C., Inoue, M., Andry, H., Fujimaki, H., Zahoor, A. and Nishihara, E. (2011) Effect of Cow Manure Biochar on Maize Productivity under Sandy Soil Condition. Soil Use and Management, 27, 205-212. https://doi.org/10.1111/j.1475-2743.2011.00340.x

[14] Alvares, R.C., Reis, E.F. and Pinto, J.F.N. (2012) Genetic Divergence in Pepper Genotypes from Southwest Goiás. Ciência e Agrotecnologia, 36, 498-506.

https://doi.org/10.1590/S1413-70542012000500002

[15] Moreira, G.R., Caliman, F.R.B., Silva, D.J.H. and Ribeiro, C.S.C. (2006) Espécies e Variedades de Pimenta. Informe Agropecuário, 27, 16-29.

[16] Ferraz, R.M., Ragassi, C.F., Heinrich, A.G., Lima, M.F., Peixoto, J.R. and Reifschneider, F.R. (2016) Caracterização Morfoagronômica Preliminar de Acessos de Pimentas Cumari. Horticultura Brasileira, 34, 498-506.

http://dx.doi.org/10.1590/s0102-053620160408

[17] Reifschneider, F.J.B. and Ribeiro, C.S.C. (2008) Cultivo. In: Ribeiro, C.S.C, Carvalho, S.I.C., Reifschneider, F.J.B., Eds., Pimentas Capsicum, Embrapa Hortaliças, Brasília.

[18] Embrapa Hortaliças (2007) Irrigação da Pimenteira.

https://sistemasdeproducao.cnptia.embrapa.br/FontesHTML/Pimenta/Pimenta_cap sicum_spp/adubacao.html 
[19] Teixeira, P.C., Donagemma, G.K., Fontana, A. and Teixeira, W.G. (2017) Manual de Métodos de Análise de Solo. 3rd Edition, Embrapa, Brasília.

[20] BRASIL. Ministério da Agricultura, Pecuária e Abastecimento (2014) Manual de Métodos Analíticos Oficiais para Fertilizantes Minerais, Orgânicos, Organominerais e Corretivos. Secretaria de Defesa Agropecuária. Coordenação de Apoio Laboratorial, Murilo Carlos Muniz Veras (Org.)-Brasília: MAPA/DAS/CGAL, 220 p.

[21] Ferreira, D.F. (2011) Sisvar: A Computer Statistical Analysis System. Ciência e Agrotecnologia, 35, 1039-1042. http://dx.doi.org/10.1590/S1413-70542011000600001

[22] Houben, D., Evrard, L. and Sonnet, P. (2013) Beneficial Effects of Biochar Application to Contaminated Soils on the Bioavailability of $\mathrm{Cd}, \mathrm{Pb}$ and $\mathrm{Zn}$ and the Biomass Production of Rapeseed (Brassica napus L.). Biomass and Bioenergy, 57, 196-204. https://doi.org/10.1016/j.biombioe.2013.07.019

[23] Silva, I.C.B., Basílio, J.J.N., Fernandes, L.A., Colen, F., Sampaio, R.A. and Frazão, L.A. (2017) Biochar from Different Residues on Soil Properties and Common Bean Production. Scientia Agricola, 74, 378-382.

http://dx.doi.org/10.1590/1678-992x-2016-0242

[24] Sparks, D. (2003) Environmental Soil Chemistry. Academic Press, San Diego. https://doi.org/10.1016/B978-0-12-656446-4.X5000-2

[25] Troeh, F.R. and Thompson, L.M. (2005) Phosphorus. In: Troeh, F.R. and Thompson, L.M., Eds., Soils and Soils Fertility, Wiley-Blackwell, New York. 